\title{
Expanding the clinical spectrum associated with defects in CNTNAP2 and NRXN1
}

\author{
Anne Gregor ${ }^{1}$, Beate Albrecht ${ }^{2}$, Ingrid Bader ${ }^{3}$, Emilia K Bijlsma ${ }^{4}$, Arif B Ekici ${ }^{1}$, Hartmut Engels ${ }^{5}$, Karl Hackmann ${ }^{6}$, \\ Denise Horn ${ }^{7}$, Juliane Hoyer ${ }^{1}$, Jakub Klapecki ${ }^{8}$, Jürgen Kohlhase ${ }^{9}$, Isabelle Maystadt ${ }^{10}$, Sandra Nagl ${ }^{11}$, Eva Prott ${ }^{2}$, \\ Sigrid Tinschert ${ }^{6}$, Reinhard Ullmann ${ }^{12}$, Eva Wohlleber ${ }^{5}$, Geoffrey Woods ${ }^{13}$, André Reis ${ }^{1}$, Anita Rauch ${ }^{14}$ and \\ Christiane Zweier ${ }^{1 *}$
}

\begin{abstract}
Background: Heterozygous copy-number and missense variants in CNTNAP2 and NRXN1 have repeatedly been associated with a wide spectrum of neuropsychiatric disorders such as developmental language and autism spectrum disorders, epilepsy and schizophrenia. Recently, homozygous or compound heterozygous defects in either gene were reported as causative for severe intellectual disability.
\end{abstract}

Methods: 99 patients with severe intellectual disability and resemblance to Pitt-Hopkins syndrome and/or suspected recessive inheritance were screened for mutations in CNTNAP2 and NRXN1. Molecular karyotyping was performed in 45 patients. In 8 further patients with variable intellectual disability and heterozygous deletions in either CNTNAP2 or NRXN1, the remaining allele was sequenced.

Results: By molecular karyotyping and mutational screening of CNTNAP2 and NRXN1 in a group of severely intellectually disabled patients we identified a heterozygous deletion in NRXN1 in one patient and heterozygous splice-site, frameshift and stop mutations in CNTNAP2 in four patients, respectively. Neither in these patients nor in eight further patients with heterozygous deletions within NRXN1 or CNTNAP2 we could identify a defect on the second allele. One deletion in NRXN1 and one deletion in CNTNAP2 occurred de novo, in another family the deletion was also identified in the mother who had learning difficulties, and in all other tested families one parent was shown to be healthy carrier of the respective deletion or mutation.

Conclusions: We report on patients with heterozygous defects in CNTNAP2 or NRXN1 associated with severe intellectual disability, which has only been reported for recessive defects before. These results expand the spectrum of phenotypic severity in patients with heterozygous defects in either gene. The large variability between severely affected patients and mildly affected or asymptomatic carrier parents might suggest the presence of a second hit, not necessarily located in the same gene.

\section{Background}

Recent data suggested that heterozygous variants or defects in NRXN1(Neurexin 1) or CNTNAP2 (contactin associated protein 2), both genes encoding neuronal cell adhesion molecules, represent susceptibility factors for a broad spectrum of neuropsychiatric disorders such as epilepsy, schizophrenia or autism spectrum disorder (ASD) with reduced penetrance and no or rather mild

\footnotetext{
* Correspondence: christiane.zweier@uk-erlangen.de

'Institute of Human Genetics, Friedrich-Alexander-University Erlangen-

Nuremberg, Erlangen, Germany

Full list of author information is available at the end of the article
}

intellectual impairment [1-23]. In contrast, biallelic defects in either gene were reported to result in fully penetrant, severe neurodevelopmental disorders. Strauss et al. reported on a homozygous stop mutation in CNTNAP2 in Old Order Amish children causing CDFE (Cortical Dysplasia - Focal Epilepsy) syndrome (MIM \#610042), characterized by cortical dysplasia and early onset, intractable focal epilepsy leading to language regression, and behavioral and mental deterioration $[24,25]$. In a former study we reported on homozygous or compound heterozygous defects in CNTNAP2 or NRXN1 in four patients with intellectual disability and

\section{Biomed Central}


epilepsy [26], resembling Pitt-Hopkins syndrome (PTHS, MIM \#610954). A possible shared synaptic mechanism that was observed in Drosophila might contribute to the similar clinical phenotypes resulting from both heterozygous and recessive defects in human CNTNAP2 or NRXN1 [26].

To further delineate the clinical phenotype associated with potentially recessive defects in any of the two genes, we screened a group of patients with either severe intellectual disability resembling Pitt-Hopkins syndrome or the phenotypes caused by recessive CNTNAP2 or NRXN1 defects. Additionally, we performed mutational testing in patients found to harbor heterozygous deletions in either gene.

\section{Methods}

\section{Patients}

Our total cohort of patients comprised four different subsets: 1. our new Pitt-Hopkins syndrome-like (PTHSL) screening group, 2. parts of our old PTHSL screening group [26], 3. a group of patients with suspected recessive inheritance, and 4. patients with known heterozygous deletions in one of the two genes. 1. The new PTHSL screening group consisted of 90 patients who were initially referred with suspected Pitt-Hopkins syndrome for diagnostic testing of the underlying gene, TCF4, which encodes transcription factor 4 . They all had severe intellectual disability and variable additional features reminiscent of the PTHS spectrum such as dysmorphic facial gestalt or breathing anomalies. Mutational testing of $T C F 4$ revealed normal results. In all of these 90 patients mutational screening of NRXN1 and CNTNAP2 was performed in the current study. Molecular Karyotyping was performed in 22 of them. This cohort does not overlap with the second subset, our old PTHSL screening group, which is a similar group of 179 patients, reported in a former study [26]. No published information on mutational screening of that group was included in the current study, but previously unpublished information on Molecular Karyotyping of 23 patients. 3. Nine patients with severe intellectual disability were referred to us specifically for CNTNAP2/NRXN1 testing because of suspected autosomal-recessive inheritance and/or phenotypic overlap with the previously published patients [26]. 4. In eight patients copy number changes in either NRXN1 or CNTNAP2 were identified in other genetic clinics. These were referred to us for mutational screening of the second allele. These patients had variable degrees of intellectual disability and various other anomalies. An overview on tested patients is given in Table 1. This study was approved by the ethics committee of the Medical Faculty, University of Erlangen-Nuremberg, and written consent was obtained from parents or guardians of the patients.

\section{Molecular Karyotyping}

Molecular karyotyping was performed in 45 patients without TCF4 mutation with an Affymetrix 6.0 SNP Array (Affymetrix, Santa Clara, CA), in accordance with the supplier's instructions. Copy-number data were analyzed with the Affymetrix Genotyping Console 3.0.2 software. In patient C3 molecular karyotyping was performed with an Affymetrix 500K array and data analysis was performed using the Affymetrix Genotyping Console 3.0.2 software.

The patients with heterozygous copy number variants (CNVs) referred for sequencing of the second allele, had been tested on different platforms. An overview on the array platforms, validation methods and segregation in the families is given in Tables 2 and 3.

\section{Mutational Screening and MLPA}

DNA samples of 107 patients were derived from peripheral blood, and if sample material was limited, whole genome amplification was performed using the Illustra GenomiPhi V2 DNA Amplification Kit (GE Healthcare, Little Chalfont, Buckinghamshire, United Kingdom) according to the manufacturer's instructions. All coding exons with exon-intron boundaries of CNTNAP2 (NM_014141) and of isoforms alpha1, alpha2 and beta of NRXN1 (NM_004801; NM_001135659; NM_138735) were screened for mutations by unidirectional direct sequencing (ABI BigDye Terminator Sequencing Kit v.3; AppliedBiosystems, Foster City, CA) with the use of an automated capillary sequencer (ABI 3730; Applied Biosystems). Mutations were confirmed with an independent PCR and bidirectional sequencing from original DNA. Primer pairs and conditions were used as previously described [26]. For splice site prediction, eight different online tools were used as indicated in Table 4. Multiplex Ligation Dependent Probe Amplification (MLPA) for all coding exons of CNTNAP2 was performed for patients $\mathrm{C} 1-\mathrm{C} 4$ as described previously [26].

\section{Results}

\section{Molecular Testing}

Mutational screening of NRXN1 in 90 TCF4 mutation negative patients and nine families with suspected recessive inheritance of severe intellectual disability did not reveal any point mutation, while in CNTNAP2 the heterozygous mutation c.1083G $>\mathrm{A}$ in the splice donor site of exon 7 was found in two patients $(\mathrm{C} 3, \mathrm{C} 4)$. Eight prediction programs (Table 4) showed diminished splice site recognition for this mutation, which is therefore predicted to result in an in-frame loss of exon 7. This possible splice site mutation was found in one of 384 control chromosomes. Furthermore, in patient $\mathrm{C} 1$ the heterozygous frameshift mutation p.D393RfsX51 in exon 
Table 1 Overview on screened patients

\begin{tabular}{|c|c|c|c|}
\hline $\begin{array}{l}\text { Patient samples used in this } \\
\text { study }\end{array}$ & $\begin{array}{c}\text { Sequencing of } N R X N 1 \text { number of } \\
\text { patients }\end{array}$ & $\begin{array}{c}\text { Sequencing of CNTNAP2 number of } \\
\text { patients }\end{array}$ & $\begin{array}{c}\text { Molecular karyotyping number of } \\
\text { patients }\end{array}$ \\
\hline $\begin{array}{l}\text { 1. new screening sample, } \\
\qquad n=90\end{array}$ & 90 & 90, including $\mathrm{C} 1-\mathrm{C} 4$ & 22, including N1 \\
\hline $\begin{array}{l}\text { 2. old screening sample[26], } \\
\qquad n=179\end{array}$ & $\begin{array}{c}\text { published [26], results not used in } \\
\text { this study }\end{array}$ & $\begin{array}{c}\text { published [26], results not used in this } \\
\text { study }\end{array}$ & 23, not published before \\
\hline 3. specific testing sample* & 9 & 9 & \\
\hline $\begin{array}{l}\text { 4. NRXN1/CNTNAP2 deletion } \\
\text { group*** }\end{array}$ & 5, N2-N6 & $3, \mathrm{C} 5-\mathrm{C} 7$ & 8, (details on arrays see Table 3 ) \\
\hline
\end{tabular}

* Patients were referred to us specifically for NRXN1/CNTNAP2 testing due to suspected autosomal recessive inheritance and/or phenotypic overlap with the previously published cases.

** Patients were referred to us because of copy number changes in either NRXN1 or CNTNAP2 for screening of the respective second allele.

Table 2 Molecular findings in NRXN1

\begin{tabular}{|c|c|c|c|c|c|c|c|c|}
\hline NRXN1 & Defect & $\begin{array}{c}\text { Array Platform } \\
\text { and } \\
\text { details of } N R X N 1 / \\
\text { CNTNAP2 deletion }\end{array}$ & $\begin{array}{l}\text { Validation of } \\
\text { Array data }\end{array}$ & Inheritance & $\begin{array}{l}\text { Carrier } \\
\text { parent }\end{array}$ & $\begin{array}{l}\text { Other non- } \\
\text { polymorphic } \\
\text { CNVs }\end{array}$ & $\begin{array}{l}\text { NRXN1 } \\
\text { sequen- } \\
\text { cing }\end{array}$ & $\begin{array}{l}\text { CNTNAP2 } \\
\text { sequen- } \\
\text { cing }\end{array}$ \\
\hline N1 & $\begin{array}{l}\text { NRXN1 deletion of } \\
\text { exons } 1-4\end{array}$ & $\begin{array}{c}\text { Affymetrix 6.0 SNP } \\
\text { Array } \\
\text { chr2:50.860.393- } \\
51.208 .000 \\
348 \text { kb (230 array } \\
\text { marker) }\end{array}$ & $\begin{array}{c}\text { MLPA as } \\
\text { reported } \\
\text { previously [26] }\end{array}$ & paternal & $\begin{array}{l}\text { healthy, } \\
\text { normal } \\
\text { intelligence }\end{array}$ & none & $\begin{array}{l}\text { no } 2^{\text {nd }} \\
\text { mutation }\end{array}$ & normal \\
\hline $\mathrm{N} 2$ & $\begin{array}{l}\text { NRXN1 deletion of } \\
\text { exons 1-18 }\end{array}$ & $\begin{array}{c}\text { Agilent } 244 \mathrm{~K} \\
\text { +customized array } \\
\text { chr2:50.270.203- } \\
51.257 .206 \\
987 \mathrm{~kb}\end{array}$ & $\begin{array}{c}\text { customized } \\
\text { Oligonucleotide } \\
\text { array }\end{array}$ & maternal & $\begin{array}{l}\text { learning } \\
\text { disabilities } \\
\text { and } \\
\text { behavioral } \\
\text { problems }\end{array}$ & none & $\begin{array}{l}\text { no } 2^{\text {nd }} \\
\text { mutation }\end{array}$ & normal \\
\hline N3 & $\begin{array}{l}\text { NRXN1 deletion of } \\
\text { exons } 1-2\end{array}$ & $\begin{array}{c}\text { Agilent 244A } \\
\text { chr2:51.011.745- } \\
51.144 .527 \\
133 \mathrm{~kb}\end{array}$ & $\begin{array}{l}\text { qPCR as } \\
\text { reported } \\
\text { previously [31] }\end{array}$ & maternal & healthy & $\begin{array}{l}\text { 21q22.3:44.534.530- } \\
\text { 44.820.473 pat dup } \\
\text { Xp22.33:0.000.001- } \\
\text { 2.710.316 mat dup }\end{array}$ & $\begin{array}{l}\text { no } 2^{\text {nd }} \\
\text { mutation }\end{array}$ & normal \\
\hline N4 & $\begin{array}{l}\text { NRXN1 deletion of } \\
\text { exons 1-4 }\end{array}$ & $\begin{array}{c}\text { Agilent 244A } \\
\text { chr2:50.800.974- } \\
51.286 .171 \\
425 \mathrm{~kb}\end{array}$ & $\begin{array}{l}\text { FISH analysis } \\
\text { with BAC clones } \\
\text { RP11-67N9 and } \\
\text { RP11-643L22 }\end{array}$ & paternal & healthy & $\begin{array}{c}15 q 26.1: 88.028 .337- \\
88.072 .545 \text { mat del } \\
\text { 16q12.1:50.773.658- } \\
\text { 51.135.179 mat } \\
\text { dup }\end{array}$ & $\begin{array}{l}\text { no } 2^{\text {nd }} \\
\text { mutation }\end{array}$ & normal \\
\hline N5 & $\begin{array}{l}\text { NRXN1 deletion of } \\
\text { exons } 3-4\end{array}$ & $\begin{array}{c}\text { Agilent 244A } \\
\text { chr2:50.861.527- } \\
51.090 .563 \\
229 \mathrm{~kb}\end{array}$ & $\begin{array}{l}\text { qPCR as } \\
\text { reported } \\
\text { previously [31] }\end{array}$ & paternal & $\begin{array}{l}\text { muscular } \\
\text { problems } \\
\& \text { stroke; } \\
\text { parents } \\
\text { consang. }\end{array}$ & none & $\begin{array}{l}\text { no } 2^{\text {nd }} \\
\text { mutation }\end{array}$ & normal \\
\hline N6 & $\begin{array}{l}\text { NRXN1 deletion of } \\
\text { exons 1-2 }\end{array}$ & $\begin{array}{c}\text { Agilent 244A } \\
\text { chr2:51.033.865- } \\
51.496 .143 \\
462 \mathrm{~kb}\end{array}$ & $\begin{array}{l}\text { Agilent } 244 \mathrm{~A} \text { of } \\
\text { the parents }\end{array}$ & de novo & & none & $\begin{array}{l}\text { no } 2^{\text {nd }} \\
\text { mutation }\end{array}$ & normal \\
\hline $\begin{array}{c}\begin{array}{c}\text { published } \\
\text { biallelic } \\
\text { defect }\end{array} \\
\text { P3, Zweier et } \\
\text { al. } 2009 \\
\mathbf{n}=\mathbf{1}[26]\end{array}$ & $\begin{array}{l}\text { NRXN1 deletion of } \\
\text { exons } 1-4+\mathrm{p} \text {. } \\
\text { S979X }\end{array}$ & $\begin{array}{c}\text { Affymetrix 6.0 SNP } \\
\text { Array } \\
113 \mathrm{~kb}\end{array}$ & & $\begin{array}{c}\text { parents } \\
\text { heterozygous } \\
\text { carriers }\end{array}$ & healthy & & & \\
\hline $\begin{array}{c}\text { published } \\
\text { heterozygous } \\
\text { defects ass. } \\
\text { with ASD } \\
\mathbf{n}=18 \\
{[5,9,14,16,22]}\end{array}$ & $\begin{array}{c}\text { 15x NRXN1 deletion } \\
{[5,14,16,22], 2 x} \\
\text { NRXN1 gain [14], } \\
1 \times \text { balanced } \\
\text { chromosomal } \\
\text { rearrangement } \\
\text { disrupting NRXN1 } \\
{[9]}\end{array}$ & $\begin{array}{l}\text { 12x Agilent 244K } \\
\text { [5], 3x NimbleGen } \\
\text { custom arrays [14], } \\
\text { 1x Affymetrix } 100 \mathrm{~K} \\
\text { Assay [16], 1x } \\
\text { Affymetrix } 10 \mathrm{~K} \\
\text { Assay [22], } \\
66 \mathrm{~kb}-5 \mathrm{Mb}\end{array}$ & & $\begin{array}{c}\text { 6x de novo } \\
{[5,16,22] ; 5 x} \\
\text { mat }[5,14] ; 4 x \\
\text { pat }[5,9] ; 3 x \\
\text { not available } \\
{[5,14]}\end{array}$ & & $\begin{array}{c}\text { 1x duplication } \\
\text { 14q24 [14] }\end{array}$ & & \\
\hline
\end{tabular}

mat, maternal; pat, paternal; dup, duplication; del, deletion; ass., associated; FISH, fluorescence in-situ hybridization; qPCR, quantitative Real-Time-PCR; nonpolymorphic CNVs: CNVs that have not been reported in the Toronto Database of Genome Variants or have not been identified in one of our molecularly karyotyped healthy control indivuals 
Table 3 Molecular findings in CNTNAP2

\begin{tabular}{|c|c|c|c|c|c|c|c|c|}
\hline CNTNAP2 & Defect & $\begin{array}{c}\text { Array Platform } \\
\text { and } \\
\text { details of } \\
\text { NRXN1/ } \\
\text { CNTNAP2 } \\
\text { deletion }\end{array}$ & $\begin{array}{l}\text { Validation of } \\
\text { Array data }\end{array}$ & Inheritance & $\begin{array}{l}\text { Carrier } \\
\text { parent }\end{array}$ & $\begin{array}{l}\text { Other non- } \\
\text { polymorphic } \\
\text { CNVs }\end{array}$ & $\begin{array}{c}N R X N 1 \\
\text { sequencing }\end{array}$ & $\begin{array}{c}\text { CNTNAP2 } \\
\text { sequencing }\end{array}$ \\
\hline C1 & $\begin{array}{c}\text { CNTNAP2 } \\
\text { C.1175_1176dup; p. } \\
\text { D393RfsX51 }\end{array}$ & $\begin{array}{c}\text { Affymetrix } 6.0 \\
\text { SNP Array, } \\
\text { normal results } \\
\text { for CNTNAP2 } \\
\text { and NRXN1 }\end{array}$ & & paternal & healthy & $\begin{array}{c}\text { chr9:9.337.920- } \\
\text { 10.207.671 mat } \\
\text { dup } \\
\text { chr13:19.104.340- } \\
\text { 19.477.398 mat } \\
\text { dup }\end{array}$ & normal & $\begin{array}{l}\text { no } 2^{\text {nd }} \\
\text { mutation; } \\
\text { MLPA } \\
\text { normal }\end{array}$ \\
\hline $\mathrm{C} 2$ & $\begin{array}{c}\text { CNTNAP2 } \\
\text { c.2153G>A, p. } \\
\text { W718X }\end{array}$ & $\begin{array}{l}\text { Affymetrix } 6.0 \\
\text { SNP Array, } \\
\text { normal results } \\
\text { for CNTNAP2 } \\
\text { and NRXN1 }\end{array}$ & & not known & $\begin{array}{l}\text { not } \\
\text { known }\end{array}$ & none & normal & $\begin{array}{l}\text { no } 2^{\text {nd }} \\
\text { mutation; } \\
\text { MLPA } \\
\text { normal }\end{array}$ \\
\hline $\mathrm{C} 3$ & $\begin{array}{c}\text { CNTNAP2 } \\
\text { c.1083G }>\text { A, splice } \\
\text { site (p.V361V) }\end{array}$ & $\begin{array}{l}\text { Affymetrix } 500 \mathrm{~K} \\
\text { SNP Array, } \\
\text { normal results } \\
\text { for CNTNAP2 } \\
\text { and NRXN1 }\end{array}$ & & paternal & healthy & none & normal & $\begin{array}{l}\text { no } 2^{\text {nd }} \\
\text { mutation; } \\
\text { MLPA } \\
\text { normal }\end{array}$ \\
\hline $\mathrm{C} 4$ & $\begin{array}{c}\text { CNTNAP2 } \\
\text { c.1083G >A, splice } \\
\text { site (p.V361V) }\end{array}$ & $\begin{array}{l}\text { Illumina } 317 \mathrm{~K} \\
\text { SNP Array, } \\
\text { normal results } \\
\text { for CNTNAP2 } \\
\text { and NRXN1 }\end{array}$ & & maternal & healthy & $\begin{array}{c}\text { pathogenic } \\
\text { frameshift } \\
\text { mutation in } \\
\text { MEF2C (P7, } \\
\text { Zweier et al. } \\
\text { 2010) [28] }\end{array}$ & normal & $\begin{array}{l}\text { no } 2^{\text {nd }} \\
\text { mutation; } \\
\text { MLPA } \\
\text { normal }\end{array}$ \\
\hline C5 & $\begin{array}{l}\text { CNTNAP2 deletion } \\
\text { of exons } 2-3\end{array}$ & $\begin{array}{c}\text { Affymetrix } 6.0 \\
\text { SNP Array } \\
\text { chr7:146.079.333- } \\
146.194 .785 \\
115 \text { kb (69 array } \\
\text { marker) }\end{array}$ & $\begin{array}{l}\text { Affymetrix } 6.0 \\
\text { SNP Array of the } \\
\text { parents }\end{array}$ & maternal & healthy & none & $\begin{array}{l}\text { normal, one } \\
\text { silent } \\
\text { variant }\end{array}$ & $\begin{array}{l}\text { no } 2^{\text {nd }} \\
\text { mutation }\end{array}$ \\
\hline $\mathrm{C} 6$ & $\begin{array}{l}\text { CNTNAP2 deletion } \\
\text { of exons 3-4 }\end{array}$ & $\begin{array}{c}\text { Illumina Human } \\
\text { 660W-Quad } \\
\text { chr7:146.144.267- } \\
146.374 .539 \\
230 \text { kb (53 array } \\
\text { marker) }\end{array}$ & $\begin{array}{l}\mathrm{qPCR} \text { as } \\
\text { reported } \\
\text { previously [32] }\end{array}$ & maternal & healthy & none & normal & $\begin{array}{l}\text { no } 2^{\text {nd }} \\
\text { mutation }\end{array}$ \\
\hline C7 & $\begin{array}{c}\text { CNTNAP2 } \\
\text { deletion of exons } \\
21-24\end{array}$ & $\begin{array}{c}\text { Agilent } 2 \times 400 \\
\text { K } \\
\text { chr7:147.702.165- } \\
148.378 .711 \\
677 \mathrm{~kb}\end{array}$ & $\begin{array}{c}\text { customized } \\
\text { Oligonucleotide } \\
\text { array }\end{array}$ & de novo & healthy & $\begin{array}{c}\text { chr7:92.394.428- } \\
\text { 92.530.356 del } \\
\text { chr7:93.464.449- } \\
94.430 .690 \text { del, } \\
\text { both de novo } \\
\text { conventional } \\
\text { karyotyping: 46, } \\
\text { XX,der(4)t(4;10) } \\
\text { (q25;q24), der(7)t } \\
(4 ; 7)(q 25 ; q 32), \\
\text { der(10)inv(10) } \\
\text { (p13q24)(7;10) } \\
\text { (q32;p13), de } \\
\text { novo }\end{array}$ & normal & $\begin{array}{l}\text { no } 2^{\text {nd }} \\
\text { mutation }\end{array}$ \\
\hline $\begin{array}{c}\begin{array}{c}\text { published } \\
\text { biallelic } \\
\text { defects }\end{array} \\
\mathrm{n}=1 \mathbf{3}[24,25]\end{array}$ & $\begin{array}{c}\text { 2x CNTNAP2 } \\
\text { deletion of exons 2- } \\
9 \text {, homozygous }[26] ; \\
\text { 1x CNTNAP2 } \\
\text { deletion of exons 5- } \\
8+\text { IVS10-1G>T }[26] ; \\
\text { 10x CNTNAP2 } \\
\text { C.3709delG, } \\
\text { homozygous }[24,25]\end{array}$ & $\begin{array}{l}\text { 2x Affymetrix } \\
500 \text { K/250 K Nsp } \\
\text { SNP Array; 1x } \\
\text { Affymetrix 6.0 } \\
\text { SNP Array [26]; } \\
\text { 10x no }\end{array}$ & & $\begin{array}{c}\text { parents } \\
\text { heterozygous } \\
\text { carriers }\end{array}$ & & & & \\
\hline
\end{tabular}


Table 3 Molecular findings in CNTNAP2 (Continued)

\begin{tabular}{ccc}
\hline $\begin{array}{c}\text { published } \\
\text { heterozygous }\end{array}$ & $\begin{array}{c}\text { 2x translocation } \\
\text { disrupting CNTNAP2 }\end{array}$ & $\begin{array}{c}3 \times \text { BAC array [7], } \\
\text { 1x NimbleGen }\end{array}$ \\
$\begin{array}{c}\text { defects } \\
\mathbf{n}=\mathbf{1 2}\end{array}$ & $\begin{array}{c}\text { disrupting CNTNAP2 } \\
\text { dis], 1x inversion }\end{array}$ & custom array \\
{$[1,3,7,12,21,33]$} & {$[3], 5 \times$ CNTNAP2 } & Mb-11 \\
& deletion [1,7,21], 4x \\
& missense variant in \\
& CNTNAP2 [3]
\end{tabular}

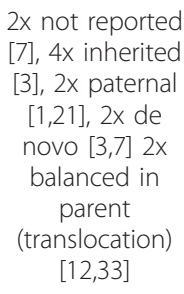

mat, maternal; pat, paternal; dup, duplication; del, deletion; ass., associated; qPCR, quantitative Real-Time-PCR; non-polymorphic CNVs: CNVs that have not been reported in the Toronto Database of Genome Variants or have not been identified in one of our molecularly karyotyped healthy control indivuals

8 and in patient $\mathrm{C} 2$ the heterozygous stop mutation p. W718X in exon 14 were identified. Due to their nature and location both truncating mutations are predicted to result in mRNA decay and loss of the affected allele. For patient $\mathrm{C} 2$ parents were not available, but all other mutations were shown to be inherited from a healthy parent. No defect on the second allele was identified in any of these patients by sequencing and subsequent MLPA-analysis of all coding exons. In 942 controls sequenced by Bakkaloglu et al. [3], no truncating mutation in CNTNAP2 was found. No CNTNAP2 deletion was found in 667 control individuals molecularly karyotyped [26].

Molecular karyotyping with an Affymetrix 6.0 SNP Array in 45 TCF4 mutation negative patients revealed a heterozygous deletion within the NRXN1 gene in one patient (N1). The father was shown to be healthy carrier, and no mutation on the second allele was found in this patient by sequencing of all coding exons.

In three patients with CNTNAP2 deletions (C5-C7) and in five patients with NRXN1 deletions (N2-N6) we could not identify any pathogenic mutation on the second allele by sequencing all coding exons. In patient N6 and in patient $\mathrm{C} 7$ the deletion within NRXN1 or CNTNAP2 was shown to be de novo. In all other families the deletion in CNTNAP2 or NRXN1 was also identified in one of the parents.

In all patients with a heterozygous defect in CNTNAP2 we also screened NRXN1 and vice versa, without observing any anomalies. An overview of localization of novel and published mutations and deletions is shown in Figure 1 and 2. Mutation and array data of novel patients are shown in Tables 2 and 3 .

\section{Clinical Findings}

Four of six patients with heterozygous CNVs in NRXN1 were severely intellectually disabled (N1-N4). Three had epilepsy and one episodic hyperbreathing. Patients N5 and N6 were only mildly intellectually disabled and N5 additionally had various malformations like choanal atresia, anal atresia, and skeletal anomalies. All patients had absent or impaired language abilities, while motor development was normal or only mildly delayed in four of them. The deletion in patient N6 was shown to be de novo, in all other families one parent was shown to be carrier of the deletion. The mother of N2 was reported to have had learning difficulties, all others were reported to be healthy and of normal intelligence. However, detailed neuropsychiatric testing was not performed. Summarized clinical details of the patients are shown in Table 5.

Table 4 Splice site prediction for splice donor variant c.1083G >A

\begin{tabular}{lll}
\hline Program & wild type score & mutant score \\
\hline NNSplice 0.9 [34] & 0.99 & 0.6 \\
HSF V2.4 [35] & 91.56 & 80.98 \\
MaxEntScan [36] & & 3.38 \\
Maximum Entropy Model & 8.37 & 9.78 \\
Maximum Dependence Decomposition Model & 11.88 & 3.88 \\
First-order Markov Model & 7.5 & 5.73 \\
Weight Matrix Model & 8.9 & 5.2 \\
Splice Site Score Calculation [37] & 8.1 & 71.36 \\
Splice Site Analyzer-Tool [38] & 83.27 & $\Delta \mathrm{G}-4$ \\
Splice Predictor [39] & $\Delta \mathrm{G}-7.1$ & splice site not recognized \\
NetGene2 [40] & 0.967 & 0.55 \\
SplicePort [41] & 0.95 & 0.26169 \\
\hline
\end{tabular}




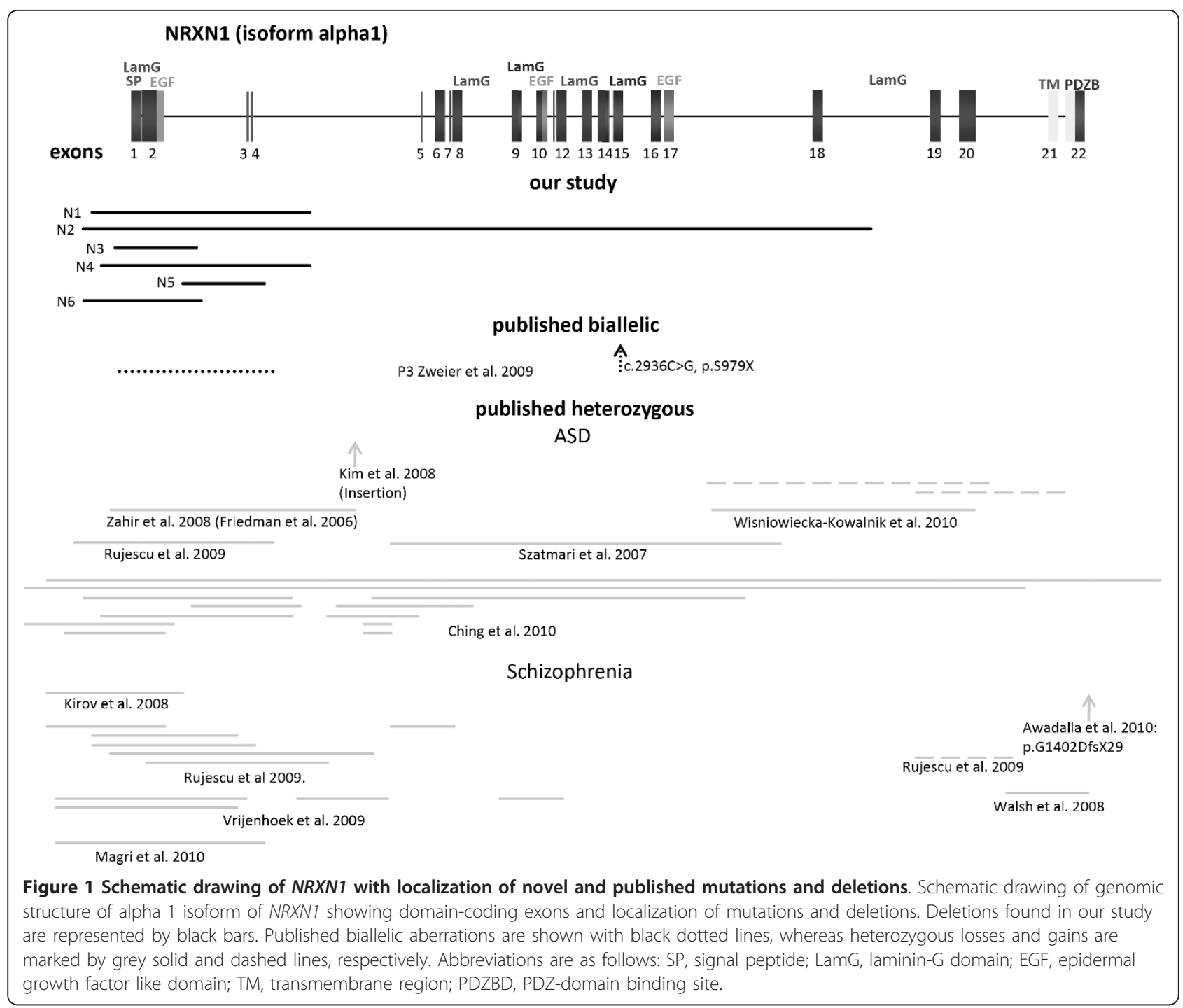

All seven patients with heterozygous defects in CNTNAP2 in this study showed severe to profound intellectual disability. Speech was lacking in four patients $(\mathrm{C} 1$, C4-C6) and reported to be simple in C7. Patient C3 lost her speech ability at age 2.5 years. Motor impairment was also severe with no walking abilities in three patients (C4-C6), patient C7 started to walk at the age of 15 months, and patients $\mathrm{C} 1$ and $\mathrm{C} 3$ lost this function at age 2.5 - 3 years. Five patients had seizures. As far as data were available, epilepsy was of early onset and difficult to treat. At least in two of the patients episodes of hyperbreathing were reported. Congenital anomalies and malformations such as tetralogy of Fallot, pyloric stenosis, and variable other anomalies or septo-optical dysplasia were reported in patients $\mathrm{C} 1$ and $\mathrm{C} 5$, respectively. In the parents shown to be carriers, no neuropsychiatric anomalies were reported. However, detailed neuropsychiatric testing was not performed.
Summarized clinical details of the patients are shown in Table 6.

\section{Discussion}

NRXN1. While the majority of the novel patients had severe intellectual disability, only two of the patients, N5 and N6, with heterozygous deletions in NRXN1 had mild intellectual disability as reported before for this kind of defects $[5,9,11,14,16]$. Additionally, patient N5 had various congenital malformations and anomalies. Interestingly, one recently published patient with a NRXN1 defect and no significant intellectual impairment was reported with similar malformations resembling the VACTERL spectrum [5]. Mild skeletal anomalies were also reported in the patient published by Zahir et al. [16]. A larger number of patients and therefore further delineation of the phenotype will probably clarify a possible relation of such malformations to NRXN1 defects. 


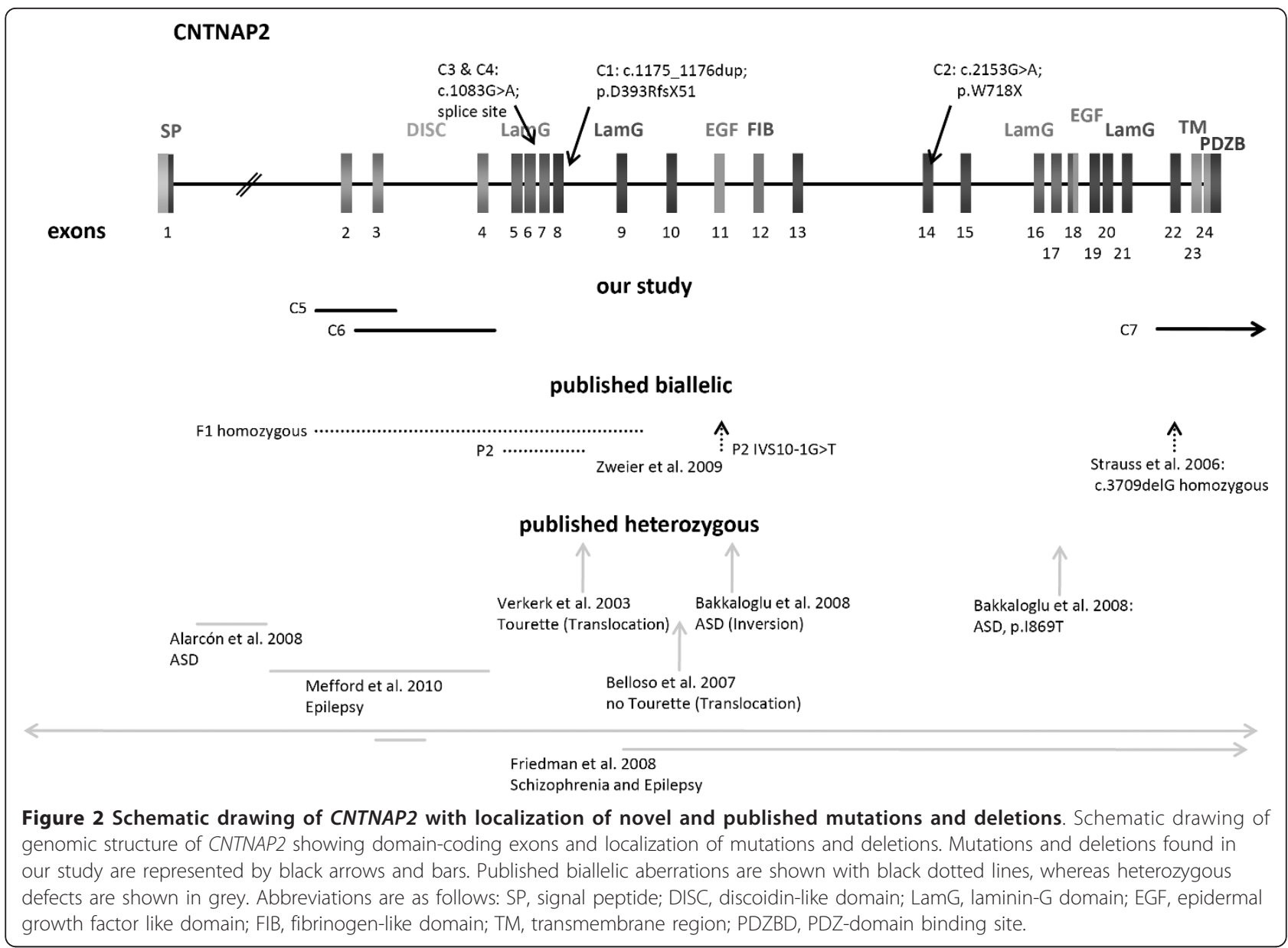

All other four patients with heterozygous NRXN1 deletions were severely intellectually disabled without specific further anomalies. Their phenotype resembled the patient reported with a compound heterozygous defect in this gene [26]. Except for patient N4, speech impairment was severe compared to a rather mild motor delay. Because of the severe phenotype in the patients in contrast to the normal or only mildly impaired intellectual function in the respective carrier parent, a defect of the second allele was suspected in the patients, but not found.

CNTNAP2. Most of the clinical aspects and the severity of intellectual disability in the herewith reported patients with heterozygous CNTNAP2 defects resembled those observed in patients with biallelic defects in CNTNAP2 reported before (Table 6). Two of the patients $(\mathrm{C} 1, \mathrm{C} 3)$ showed language and motor regression correlating with onset of epilepsy. All others showed lacking or severely impaired speech development. However, in contrast to the published patients with recessive defects and normal or only mildly delayed motor development $[24,26]$, all but one patients in this study also showed severe motor retardation. We could not identify a defect on the second allele in any of the novel patients. In most of the families the defect was inherited from a healthy parent. Despite a significantly higher frequency ( $p<0.01$, Fisher's exact test) of two truncating mutations in our cohort of 99 severely to profoundly intellectually disabled patients compared to no truncating mutation in 942 normal controls [3] definite proof that the respective mutation is fully responsible for the phenotype is so far lacking. This also applies to the other identified defects in CNTNAP2 or NRXN1.

Congenital malformations as described in patients $\mathrm{C} 1$ or C5 (Table 6) have not yet been reported in any other patient with a CNTNAP2 defect. Furthermore, the fact that the expression of the gene is restricted to the nervous system [27] does not explain these anomalies. Therefore, another genetic cause for these malformations might exist. Thus it is difficult to define if the intellectual disability is associated with the CNTNAP2 mutation at all in these patients. Other factors like premature complicated birth in patient C6 might contribute to impaired intellectual function. $\mathrm{C} 3$ and $\mathrm{C} 4$ carried the 
Table 5 Clinical findings associated with defects in NRXN1

\begin{tabular}{|c|c|c|c|c|c|c|c|c|c|c|}
\hline NRXN1 & $\begin{array}{c}\text { Sex } \\
\& \\
\text { Age }\end{array}$ & ID & Speech & $\begin{array}{l}\text { Age of } \\
\text { Walking }\end{array}$ & $\begin{array}{c}\text { Seizures } \\
\text { age of } \\
\text { onset }\end{array}$ & $\begin{array}{c}\text { Birth } \\
\text { parameters } \\
\text { Weight, } \\
\text { Heigth, } \\
\text { OFC }\end{array}$ & $\begin{array}{l}\text { Weight } \\
\text { Height } \\
\text { OFC }\end{array}$ & $\begin{array}{c}\text { Behavioral } \\
\text { anomalies/ } \\
\text { Stereotypies }\end{array}$ & $\begin{array}{c}\text { Facial } \\
\text { dysmorphisms }\end{array}$ & Other findings \\
\hline N1 & $\begin{array}{l}m \\
14 y\end{array}$ & Severe & $\begin{array}{l}\text { at 3y: max. } \\
10 \text { single } \\
\text { words, lost } \\
\text { this function }\end{array}$ & $14 \mathrm{mo}$ & yes & $\begin{array}{l}2900 \mathrm{~g} \\
52 \mathrm{~cm} \\
34 \mathrm{~cm}\end{array}$ & $\begin{array}{l}\text { P25-P50 } \\
\text { P25-P50 } \\
\text { P90 }\end{array}$ & $\begin{array}{c}\text { yes, } \\
\text { puts objects } \\
\text { in his mouth }\end{array}$ & $\begin{array}{c}\text { large mouth, } \\
\text { widely spaced } \\
\text { teeth, } \\
\text { upslanting } \\
\text { palpebral } \\
\text { fissures, } \\
\text { strabism }\end{array}$ & hyperbreathing \\
\hline N2 & $\begin{array}{l}\mathrm{m}, \\
6 y\end{array}$ & Severe & $\begin{array}{l}\text { at } 24 \mathrm{mo}: \\
\text { single words } \\
\text { and two } \\
\text { word } \\
\text { combinations, } \\
\text { receptive } \\
\text { better than } \\
\text { expressive }\end{array}$ & $16 \mathrm{mo}$ & none & $\begin{array}{c}3740 \mathrm{~g} \\
51 \mathrm{~cm} \\
38.5 \mathrm{~cm}\end{array}$ & $\begin{array}{c}\text { Normal } \\
<\text { P3 } \\
>\text { P95 }\end{array}$ & none & $\begin{array}{l}\text { macrocephaly } \\
\text { (also maternal } \\
\text { and paternal), } \\
\text { large mouth, } \\
\text { retrogenia }\end{array}$ & $\begin{array}{c}\text { muscular } \\
\text { hypotonia, MRl: } \\
\text { wide ventricles }\end{array}$ \\
\hline N3 & $\begin{array}{c}\mathrm{m} \\
3 \mathrm{y} \\
4 \mathrm{mo}\end{array}$ & Severe & $\begin{array}{l}\text { no active } \\
\text { speech }\end{array}$ & $14 \mathrm{mo}$ & none & $\begin{array}{l}3350 \mathrm{~g} \\
52 \mathrm{~cm} \\
35 \mathrm{~cm}\end{array}$ & $\begin{array}{l}\text { P50-P75 } \\
\text { P75-P90 } \\
\text { P50-P75 }\end{array}$ & yes & none & none \\
\hline N4 & $\begin{array}{c}f, \\
16 y\end{array}$ & Severe & none & no & $\begin{array}{c}\text { grand } \\
\text { mal } \\
4 y\end{array}$ & $\begin{array}{l}3530 \mathrm{~g} \\
51 \mathrm{~cm} \\
33 \mathrm{~cm}\end{array}$ & $\begin{array}{l}\mathrm{P} 10-\mathrm{P} 25 \\
\mathrm{P} 25-\mathrm{P} 50 \\
<\mathrm{P} 5\end{array}$ & $\begin{array}{c}\text { yes, } \\
\text { hand licking }\end{array}$ & $\begin{array}{l}\text { broad nasal tip, } \\
\text { pointed chin }\end{array}$ & drooling, friendly \\
\hline N5 & $\begin{array}{l}\mathrm{m} \\
21 \mathrm{y}\end{array}$ & Mild & impaired & $\begin{array}{l}\text { not } \\
\text { known }\end{array}$ & $\begin{array}{l}\text { grand } \\
\text { mal, } \\
\text { 6y (until } \\
\text { age 11y) }\end{array}$ & $\begin{array}{l}3300 \mathrm{~g} \\
51 \mathrm{~cm} \\
33 \mathrm{~cm}\end{array}$ & $\begin{array}{l}\text { P3-P10 } \\
<\text { P3 } \\
\text { P50 }\end{array}$ & none & $\begin{array}{c}\text { mild facial } \\
\text { asymmetry, } \\
\text { small ears, } \\
\text { broad nose, } \\
\text { broad mouth, } \\
\text { bushy eye } \\
\text { brows, high } \\
\text { arched palate, } \\
\text { cleft lip }\end{array}$ & $\begin{array}{c}\text { pectus } \\
\text { excavatum, } \\
\text { single transverse } \\
\text { palmar crease, } \\
\text { choanal atresia, } \\
\text { anal atresia, thick } \\
\text { finger joints, } \\
\text { ureter stenosis, } \\
\text { delayed bone } \\
\text { age, } \\
\text { spondyloptosis } \\
\text { L5/S1 }\end{array}$ \\
\hline N6 & $\begin{array}{l}f, 6 y \\
3 m o\end{array}$ & Mild & $\begin{array}{c}2 \text { y: first } \\
\text { words, } \\
\text { speech delay } \\
\text { mainly } \\
\text { affecting } \\
\text { active speech }\end{array}$ & $21 \mathrm{mo}$ & none & $\begin{array}{l}2820 \mathrm{~g} \\
50 \mathrm{~cm} \\
35 \mathrm{~cm}\end{array}$ & $\begin{array}{c}\text { P10-P25 } \\
\text { P3 } \\
\text { P10-P25 }\end{array}$ & none & protruding ears & $\begin{array}{c}\text { muscular } \\
\text { hypotonia } \\
\text { (improved), } \\
\text { scapulae alatae, } \\
\text { mild lordosis, } \\
\text { tendency to } \\
\text { diarrhea }\end{array}$ \\
\hline $\begin{array}{l}\text { published } \\
\text { biallelic } \\
\text { defect } \\
\text { P3, Zweier et } \\
\text { al. 2009 } \\
\mathbf{N}=1 \text { [26] }\end{array}$ & $\begin{array}{c}f, \\
18 y\end{array}$ & Severe & none & $2 y$ & none & $\begin{array}{l}3450 \mathrm{~g} \\
\text { normal }\end{array}$ & $\begin{array}{l}\text { P50-P75 } \\
\text { P50-P75 } \\
\text { P25 }\end{array}$ & $\begin{array}{c}\text { yes, } \\
\text { hypermotoric } \\
\text { behavior }\end{array}$ & $\begin{array}{l}\text { broad mouth, } \\
\text { strabism, } \\
\text { protruding } \\
\text { tongue }\end{array}$ & $\begin{array}{c}\text { excessive } \\
\text { drooling, } \\
\text { developmental } \\
\text { regression, } \\
\text { abnormal sleep- } \\
\text { wake-cycles, } \\
\text { decreased deep- } \\
\text { tendon reflexes } \\
\text { upper } \\
\text { extremities, } \\
\text { hyperbreathing }\end{array}$ \\
\hline $\begin{array}{l}\text { published } \\
\text { heterozygous } \\
\text { defects ass. } \\
\text { with ASD } \\
\mathbf{N}=1 \mathbf{8} \\
{[5,9,14,16,22]}\end{array}$ & & $\begin{array}{c}\text { 7x normal } \\
{[5], 3 x} \\
\text { learning } \\
\text { problems } \\
{[5,14] 2 x} \\
\text { dev. Delay } \\
\text { [5,22], 3x } \\
\text { mild ID } \\
{[9,14,16], 2 x} \\
\text { moderate } \\
\text { ID [5] }\end{array}$ & $\begin{array}{c}\text { 14x language } \\
\text { delay } \\
{[5,14,16,22]}\end{array}$ & $\begin{array}{c}5 x \\
\text { motor } \\
\text { delay } \\
{[5,16]}\end{array}$ & $\begin{array}{c}1 \times \text { yes } \\
{[5]}\end{array}$ & $\begin{array}{l}\text { not } \\
\text { reported }\end{array}$ & $\begin{array}{l}\text { not } \\
\text { reported }\end{array}$ & $\begin{array}{c}\text { 11x ASD or } \\
\text { Asperger } \\
\text { syndrome } \\
{[5,9,14,16,22]}\end{array}$ & $\begin{array}{l}11 \times \text { mild } \\
\text { dysmorphic } \\
\text { features } \\
{[5,14,16]}\end{array}$ & $\begin{array}{c}1 \times \text { VACTERL } \\
\text { association [5], } \\
1 \times \text { mild skeletal } \\
\text { anomalies [16], } \\
4 x \text { hypotonia, } 2 x \\
\text { ventricular } \\
\text { septum defect, } \\
\text { 3x hemangioma } \\
{[5]}\end{array}$ \\
\hline
\end{tabular}

TOF, tetralogy of Fallot; $f$, female; $m$, male; $y$, year; mo, month; ASD, autism spectrum disorder; published reports on CNTNAP2 and NRXN1: only papers containing clinical data are cited; ass., associated; P, centile; ass., associated 
Table 6 Clinical findings associated with defects in CNTNAP2

\begin{tabular}{|c|c|c|c|c|c|c|c|c|c|c|}
\hline CNTNAP2 & $\begin{array}{l}\text { Sex \& } \\
\text { Age }\end{array}$ & ID & Speech & $\begin{array}{l}\text { Age of } \\
\text { Walking }\end{array}$ & $\begin{array}{l}\text { Seizures } \\
\text { age of } \\
\text { onset }\end{array}$ & $\begin{array}{l}\text { Birth } \\
\text { parameters } \\
\text { Weight, } \\
\text { Heigth, } \\
\text { OFC } \\
\end{array}$ & $\begin{array}{l}\text { Weight } \\
\text { Height } \\
\text { OFC }\end{array}$ & $\begin{array}{l}\text { Behavioral } \\
\text { anomalies/ } \\
\text { Stereotypies }\end{array}$ & Facial dysmorphisms & Other findings \\
\hline C1 & $f, 8 y$ & Severe & none & $\begin{array}{l}2 y \text { with aid, } \\
\text { lost this } \\
\text { function } \\
\text { (3y) }\end{array}$ & $\begin{array}{l}\text { yes, resist. } \\
\text { to } \\
\text { treatment }\end{array}$ & $\begin{array}{l}2430 \mathrm{~g} \\
45 \mathrm{~cm} \\
\text { not } \\
\text { reported }\end{array}$ & $\begin{array}{l}<\mathrm{P} 3 \\
<\mathrm{P} 3 \\
<\mathrm{P} 3\end{array}$ & $\begin{array}{l}\text { hand } \\
\text { movements }\end{array}$ & $\begin{array}{c}\text { synophrys, long } \\
\text { eyelashes, prominent } \\
\text { columella, short } \\
\text { philtrum, arched palate, } \\
\text { widely spaced teeth, } \\
\text { prominent jaw }\end{array}$ & $\begin{array}{c}\text { happy, affectionate, TOF, pyloric stenosis, } \\
\text { vesicoureteric reflux, agenesis of labia } \\
\text { minora, hirsutism, tapering fingers }\end{array}$ \\
\hline $\mathrm{C} 2$ & m, 18y & Severe & $?$ & $?$ & $\begin{array}{l}\text { complex, } \\
\text { early } \\
\text { onset }\end{array}$ & $?$ & $?$ & $?$ & & hyperbreathing, apnoe episodes \\
\hline C3 & $f, 11 y$ & Severe & $\begin{array}{l}\text { few words, lost } \\
\text { this function }\end{array}$ & $\begin{array}{l}2,5 y \text {, lost } \\
\text { this } \\
\text { function }\end{array}$ & $3 y$ & $3510 \mathrm{~g}$ & $\begin{array}{l}\text { P10 } \\
<\text { P3 } \\
\text { P10 }\end{array}$ & yes & $\begin{array}{l}\text { broad mouth, } \\
\text { protruding tongue }\end{array}$ & $\begin{array}{c}\text { develop. regression from } 15 \text { m, } \\
\text { swallowing problems, nocturnal } \\
\text { laughing, scoliosis, spastic tetraparesis, } \\
\text { hyperreflexia, constipation, } \\
\text { hyperbreathing }\end{array}$ \\
\hline $\begin{array}{l}\text { C4 } \\
\text { Zweier et al., } \\
2010[28]\end{array}$ & $f, 7 y$ & Profound & none & no & $3-6 \mathrm{mo}$ & $3400 \mathrm{~g}$ & $\begin{array}{l}\text { P5 } \\
<\text { P2 } \\
\text { P50 }\end{array}$ & yes & $\begin{array}{l}\text { broad forehead, } \\
\text { prominent ear lobes, } \\
\text { widely spaced teeth, } \\
\text { tented upper lip }\end{array}$ & $\begin{array}{c}\text { exotropia, heterochromasia, high pain } \\
\text { threshold, cold feet, sleeping problems, } \\
\text { joint hyperlaxity }\end{array}$ \\
\hline C5 & f, $2 y 8 m o$ & Profound & none & $\begin{array}{c}\text { no, } \\
\text { no crawling }\end{array}$ & none & $\begin{array}{l}4030 \mathrm{~g} \\
53 \mathrm{~cm} \\
38 \mathrm{~cm}\end{array}$ & $\begin{array}{l}\text { P75 } \\
\text { P25-50 }\end{array}$ & & $\begin{array}{l}\text { high arched palate, } \\
\text { upslanting palpebral } \\
\text { fissures, small teeth, } \\
\text { prominent forehead }\end{array}$ & $\begin{array}{c}\text { septo-optical dysplasia, MRl: agenesis of } \\
\text { septum pellucidum }\end{array}$ \\
\hline C6 & $f, 8 y$ & Profound & none & no & $\begin{array}{l}\text { yes, resist. } \\
\quad \text { to } \\
\text { treatment }\end{array}$ & $\begin{array}{l}1160 \mathrm{~g} \\
35 \mathrm{~cm} \\
28 \mathrm{~cm}\end{array}$ & $\begin{array}{l}<\mathrm{P} 3 \\
<\mathrm{P} 3 \\
<\mathrm{P} 5\end{array}$ & & $\begin{array}{l}\text { mild synophrys, low } \\
\text { set, large ears, fleshy } \\
\text { ear lobes, thin upper } \\
\text { lip, low frontal hairline }\end{array}$ & $\begin{array}{c}\text { birth at } 29^{\text {th }} \text { week of gestation, } \\
\text { blindness, hydrocephalus, ductus } \\
\text { arteriosus, syndactyly toes } 2-3, \\
\text { hypotonia, spasticity of legs, obstipation, } \\
\text { liquid uptake by PEG tube }\end{array}$ \\
\hline C7 & $f, 8 y$ & $\begin{array}{l}\text { moderate to } \\
\text { severe }\end{array}$ & simple & $15 \mathrm{mo}$ & none & $\begin{array}{l}3860 \mathrm{~g} \\
54 \mathrm{~cm} \\
34 \mathrm{~cm}\end{array}$ & $\begin{array}{l}\text { P25-P50 } \\
\text { P50 } \\
<\text { P5 }\end{array}$ & $\begin{array}{l}\text { suspected in } \\
\text { infancy }\end{array}$ & $\begin{array}{c}\text { epicanthal folds, tented } \\
\text { upper lip, short } \\
\text { columella, bulbous } \\
\text { nose }\end{array}$ & $\begin{array}{c}\text { overfriendliness, pubertas praecox, } \\
\text { delayed bone age, retentive memory, } \\
\text { excessive empathy, autoagressive } \\
\text { behavior, flat feet }\end{array}$ \\
\hline $\begin{array}{l}\text { published } \\
\text { biallelic } \\
\text { defects } \\
\mathrm{N}=13[24,25]\end{array}$ & $\begin{array}{l}2 x f, 1 x \\
m, 10 x \\
\text { not } \\
\text { reported, } \\
1-20 y\end{array}$ & Severe & $\begin{array}{l}2 \times \text { no, } 1 \times \text { single } \\
\text { words [26], 10x } \\
\text { yes, but } \\
\text { regression } \\
{[24,25]}\end{array}$ & $\begin{array}{c}2 \times \text { normal, } \\
1 \times \text { not } \\
\text { known }[26] \\
10 x 16 \mathrm{mo}- \\
30 \mathrm{mo} \\
{[24,25]}\end{array}$ & $\begin{array}{l}\text { 13x yes, } \\
4 \mathrm{mo}^{-} \\
30 \mathrm{mo}\end{array}$ & $\begin{array}{c}\text { not } \\
\text { reported }\end{array}$ & $\begin{array}{l}<\text { P3- } \\
\text { normal } \\
\text { not } \\
\text { reported } \\
<\text { P3-P99 }\end{array}$ & $\begin{array}{l}8 \times \text { yes }[24,26] \\
1 \times \text { tooth } \\
\text { grinding and } \\
\text { repetitive } \\
\text { hand } \\
\text { movements } \\
{[26]}\end{array}$ & $\begin{array}{l}2 \times \text { wide mouth and } \\
\text { thick lips [26] }\end{array}$ & $\begin{array}{c}\text { 1x dry skin, 1x regression, 1x cerebellar } \\
\text { hypoplasia, } \\
3 x \text { hyperbreathing [26], 10x } \\
\text { developmental regression with onset of } \\
\text { seizures, 9x decreased deep tendon } \\
\text { reflexes [24,25], 4x MRI: cortical dysplasia } \\
\text { [24], 1x MRI: leukomalacia, 1x } \\
\text { hepatosplenomegaly [25] }\end{array}$ \\
\hline $\begin{array}{l}\text { published } \\
\text { heterozygous } \\
\text { defects } \\
\mathbf{N}=12 \\
{[1,3,7,12,21,33]}\end{array}$ & & $\begin{array}{c}6 x \text { not reported } \\
{[1,3,21], 1 x} \\
\text { normal }[7], 2 x \\
\text { mild-moderate } \\
{[3,7], 3 x \text { severe }} \\
{[7,12,33]}\end{array}$ & $\begin{array}{c}\text { 6x not reported } \\
{[1,3,21], 1 x} \\
\text { normal }[7], 3 x \\
\text { speech } \\
\text { impairment } \\
{[7,12] 2 x \text { no }} \\
{[7,33]}\end{array}$ & $\begin{array}{l}11 \times \text { not } \\
\text { reported } \\
{[1,3,7,12,21]} \\
1 \times \text { no }[33]\end{array}$ & $\begin{array}{c}5 x \text { not } \\
\text { reported } \\
{[1,3], 2 x} \\
\text { no }[12,33] \\
5 x \text { yes } \\
{[3,7,21]} \\
\text { Oy-34y }\end{array}$ & $\begin{array}{l}\text { not } \\
\text { reported }\end{array}$ & $\begin{array}{l}\text { not } \\
\text { reported }\end{array}$ & $8 x$ yes $[1,3,7]$ & not reported & $\begin{array}{c}\text { 1x multiple congenital malformations } \\
\text { [33], 1x Gilles de la Tourette syndrome } \\
{[12], 3 \times \text { Schizophrenia [7] }}\end{array}$ \\
\hline
\end{tabular}

TOF, tetralogy of Fallot; $f$, female; $m$, male; $y$, year; mo, month; ASD, autism spectrum disorder; published reports on CNTNAP2 and NRXN1: only papers containing clinical data are cited; ass., associated; $\mathrm{P}$, centile; ass., associated 
same splice site mutation and both showed a similar phenotype with severe intellectual disability and seizures, C3 also with breathing anomalies. In a parallel research project, a mutation in the $M E F 2 C$ gene was identified in patient $\mathrm{C} 4$ and shown to be capable of causing all of her symptoms [28]. Therefore, it remains unclear if this splice mutation has a pathogenic effect at all, or only a mild effect that is masked by the severe consequences of the $M E F 2 C$ mutation. The fact that this variant is supposed to lead to an in-frame loss of a single exon with a possibly milder effect than more deleterious defects supports the idea of no or only minor relevance of this splice mutation. Regarding the relatively high frequency of the splice site mutation in two families and one control, a founder effect might be considered, however, common regional background in these persons is not obvious.

Expanding the observations from previous studies we now found that heterozygous defects in CNTNAP2 or NRXN1 can also be seen in association with severe intellectual disability. Possible explanations might be: 1. No pathogenic relevance of the identified defect. This might indeed be the case for those patients with a "mild mutation" such as the splice-site mutation in CNTNAP2, or for patients with an atypical phenotype or congenital malformations. In those, the true causative defect might not be detected yet. However, published data and our data together still support a pathogenic role for both genes in neurodevelopmental disorders. 2. Inability to identify a defect on the second allele in spite of extensive screening for mutations and/ or deletions. However, mutations in regulatory elements or in additional alternative isoforms cannot be excluded in any case. 3. A larger phenotypic variability associated with heterozygous defects in each gene. The finding of homozygous or compound heterozygous defects in previous patients with severe phenotypes [24-26] indicates the existence of second hits or additional major contributors. These might not necessarily be affecting the same gene. Only recently, a two-hit model for severe developmental delay in patients with a recurrent 16p12.1 microdeletion was postulated [29]. This might also be the case for microdeletions or even point mutations within a single gene as already reported for digenic inheritance in specific ciliopathies like Bardet-Biedl syndrome [30]. In four of our patients additional de novo or parentally inherited CNVs were identified (see Tables 2 and 3), however, the significance of these CNVs is unclear. The possible functional synaptic link between CNTNAP2 and NRXN1 [24-26] prompted us to screen CNTNAP2 in patients with NRXN1 defects and vice versa, however, without any mutation detected.

\section{Conclusion}

We found heterozygous defects in CNTNAP2 and NRXN1 in patients with severe intellectual disability, therefore expanding the clinical spectrum associated with monoallelic defects in either gene. This large variability implicates difficulties for genetic counseling in such families. To explain the larger phenotypic variability and severity in some patients we suggest a contribution of major additional genetic factors. To identify these possible contributors and modifiers will be a great challenge for the near future.

\section{Acknowledgements}

We thank the contributing clinicians, the patients and their families for participating. We thank Christine Zeck-Papp for excellent technical assistance and Dr. D. Müller and Dr. A. Kobelt for providing clinical details. This study was funded by a grant from the DFG (ZW184/1-1) and by the German MRNET funded by the BMBF.

\section{Author details}

${ }^{1}$ Institute of Human Genetics, Friedrich-Alexander-University ErlangenNuremberg, Erlangen, Germany. ${ }^{2}$ Institut für Humangenetik,

Universitätsklinikum, Universität Duisburg-Essen, Essen, Germany.

${ }^{3}$ Department of Medical Genetics, Kinderzentrum Munich, Munich, Germany.

${ }^{4}$ Department of Clinical Genetics, Leiden University Medical Centre, Leiden,

The Netherlands. ${ }^{5}$ Institute of Human Genetics, Rheinische FriedrichWilhelms-University, Bonn, Germany. Institut für Klinische Genetik,

Medizinische Fakultät Carl Gustav Carus, Technische Universität Dresden, Dresden, Germany. ${ }^{7}$ Institute of Medical Genetics and Human Genetics,

Charité - Universitätsmedizin Berlin, Berlin, Germany. ${ }^{8}$ Department of Medical Genetics, Institute of Mother and Child, Warsaw, Poland. ${ }^{9}$ Center for Human Genetics, Freiburg, Germany. ${ }^{10}$ Centre de Genetique Humaine, Institut de Pathologie et de Genetique, Gosselies (Charleroi), Belgium. ${ }^{11}$ Synlab Medizinisches Versorgungszentrum Humane Genetik Munich GmbH, Munich, Germany. ${ }^{12}$ Department of Human Molecular Genetics, Max Planck Institute for Molecular Genetics, Berlin, Germany. ${ }^{13}$ Cambridge Institute for Medical Research, Wellcome Trust/MRC Building, Addenbrooke's Hospital, Cambridge, UK. ${ }^{14}$ Institute of Medical Genetics, University of Zurich, Zurich-

Schwerzenbach, Switzerland.

\section{Authors' contributions}

$B A, I B, E K B, D H, J H, J K I, I M, E P, S T$, EW, and GW acquired and provided clinical data and samples of their patients. AG, ABE, HE, KH, JKo, SN, RU, ARe, and $\mathrm{CZ}$ created and analysed the molecular data. ARe and ARa revised the manuscript critically for important intellectual content. CZ designed and supervised the project, and together with AG drafted the manuscript. All authors read and approved the manuscript.

\section{Competing interests}

The authors declare that they have no competing interests.

Received: 17 May 2011 Accepted: 9 August 2011

Published: 9 August 2011

\section{References}

1. Alarcon M, Abrahams BS, Stone JL, Duvall JA, Perederiy JV, Bomar JM, Sebat J, Wigler M, Martin CL, Ledbetter DH, Nelson SF, Cantor RM, Geschwind DH: Linkage, association, and gene-expression analyses identify CNTNAP2 as an autism-susceptibility gene. AmJHumGenet 2008, 82(1):150-159.

2. Arking DE, Cutler DJ, Brune CW, Teslovich TM, West K, Ikeda M, Rea A, Guy M, Lin S, Cook EH, Chakravarti A: A common genetic variant in the neurexin superfamily member CNTNAP2 increases familial risk of autism. AmJHumGenet 2008, 82(1):160-164.

3. Bakkaloglu B, O'Roak BJ, Louvi A, Gupta AR, Abelson JF, Morgan TM, Chawarska K, Klin A, Ercan-Sencicek AG, Stillman AA, Tanriover G, 
Abrahams BS, Duvall JA, Robbins EM, Geschwind DH, Biederer T, Gunel M, Lifton RP, State MW: Molecular cytogenetic analysis and resequencing of contactin associated protein-like 2 in autism spectrum disorders. AmJHumGenet 2008, 82(1):165-173.

4. Bucan M, Abrahams BS, Wang K, Glessner JT, Herman El, Sonnenblick LI, varez Retuerto Al, Imielinski M, Hadley D, Bradfield JP, Kim C, Gidaya NB, Lindquist I, Hutman T, Sigman M, Kustanovich V, Lajonchere CM, Singleton A, Kim J, Wassink TH, McMahon WM, Owley T, Sweeney JA, Coon H, Nurnberger JI, Li M, Cantor RM, Minshew NJ, Sutcliffe JS, Cook EH, et al: Genome-wide analyses of exonic copy number variants in a familybased study point to novel autism susceptibility genes. PLoSGenet 2009, 5(6):e1000536.

5. Ching MS, Shen Y, Tan WH, Jeste SS, Morrow EM, Chen X, Mukaddes NM, Yoo SY, Hanson E, Hundley R, Austin C, Becker RE, Berry GT, Driscoll K, Engle EC, Friedman S, Gusella JF, Hisama FM, Irons MB, Lafiosca T, LeClair E, Miller DT, Neessen M, Picker JD, Rappaport L, Rooney CM, Sarco DP, Stoler JM, Walsh CA, Wolff RR, et al: Deletions of NRXN1 (neurexin-1) predispose to a wide spectrum of developmental disorders. Am J Med Genet B Neuropsychiatr Genet 2010, 153B(4):937-947.

6. Feng J, Schroer R, Yan J, Song W, Yang C, Bockholt A, Cook EH Jr, Skinner C, Schwartz CE, Sommer SS: High frequency of neurexin 1 beta signal peptide structural variants in patients with autism. Neuroscilett 2006, 409(1):10-13.

7. Friedman Jl, Vrijenhoek T, Markx S, Janssen IM, van dV, Faas BH, Knoers NV, Cahn W, Kahn RS, Edelmann L, Davis KL, Silverman JM, Brunner HG, van Kessel AG, Wijmenga C, Ophoff RA, Veltman JA: CNTNAP2 gene dosage variation is associated with schizophrenia and epilepsy. MolPsychiatry 2008, 13(3):261-266.

8. Glessner JT, Wang K, Cai G, Korvatska O, Kim CE, Wood S, Zhang H, Estes A, Brune CW, Bradfield JP, Imielinski M, Frackelton EC, Reichert J, Crawford EL, Munson J, Sleiman PM, Chiavacci R, Annaiah K, Thomas K, Hou C, Glaberson W, Flory J, Otieno F, Garris M, Soorya L, Klei L, Piven J, Meyer KJ, Anagnostou E, Sakurai T, et al: Autism genome-wide copy number variation reveals ubiquitin and neuronal genes. Nature 2009, 459(7246):569-573.

9. Kim HG, Kishikawa S, Higgins AW, Seong IS, Donovan DJ, Shen Y, Lally E, Weiss LA, Najm J, Kutsche K, Descartes M, Holt L, Braddock S, Troxell R, Kaplan L, Volkmar F, Klin A, Tsatsanis K, Harris DJ, Noens I, Pauls DL, Daly MJ, MacDonald ME, Morton CC, Quade BJ, Gusella JF: Disruption of neurexin 1 associated with autism spectrum disorder. AmJHumGenet 2008, 82(1):199-207.

10. Marshall CR, Noor A, Vincent JB, Lionel AC, Feuk L, Skaug J, Shago M, Moessner R, Pinto D, Ren Y, Thiruvahindrapduram B, Fiebig A, Schreiber S, Friedman J, Ketelaars CE, Vos YJ, Ficicioglu C, Kirkpatrick S, Nicolson R, Sloman L, Summers A, Gibbons CA, Teebi A, Chitayat D, Weksberg R, Thompson A, Vardy C, Crosbie V, Luscombe S, Baatjes R, et al: Structural variation of chromosomes in autism spectrum disorder. AmJHumGenet 2008, 82(2):477-488.

11. Rujescu D, Ingason A, Cichon S, Pietilainen OP, Barnes MR, Toulopoulou T, Picchioni M, Vassos E, Ettinger U, Bramon E, Murray R, Ruggeri M, Tosato S, Bonetto C, Steinberg S, Sigurdsson E, Sigmundsson T, Petursson H, Gylfason A, Olason Pl, Hardarsson G, Jonsdottir GA, Gustafsson O, Fossdal R, Giegling I, Moller HJ, Hartmann AM, Hoffmann P, Crombie C, Fraser G, et al: Disruption of the neurexin 1 gene is associated with schizophrenia. HumMolGenet 2009, 18(5):988-996.

12. Verkerk AJ, Mathews CA, Joosse M, Eussen BH, Heutink P, Oostra BA: CNTNAP2 is disrupted in a family with Gilles de la Tourette syndrome and obsessive compulsive disorder. Genomics 2003, 82(1):1-9.

13. Vernes SC, Newbury DF, Abrahams BS, Winchester L, Nicod J, Groszer M, Alarcon M, Oliver PL, Davies KE, Geschwind DH, Monaco AP, Fisher SE: A functional genetic link between distinct developmental language disorders. NEnglJMed 2008, 359(22):2337-2345.

14. Wisniowiecka-Kowalnik B, Nesteruk M, Peters SU, Xia Z, Cooper ML, Savage S, Amato RS, Bader P, Browning MF, Haun CL, Duda AW, Cheung SW, Stankiewicz P: Intragenic rearrangements in NRXN1 in three families with autism spectrum disorder, developmental delay, and speech delay. Am J Med Genet B Neuropsychiatr Genet 2010, 153B(5):983-993.

15. Yan J, Noltner K, Feng J, Li W, Schroer R, Skinner C, Zeng W, Schwartz CE, Sommer SS: Neurexin 1alpha structural variants associated with autism. Neuroscilett 2008, 438(3):368-370.
16. Zahir FR, Baross A, Delaney AD, Eydoux P, Fernandes ND, Pugh T, Marra MA, Friedman JM: A patient with vertebral, cognitive and behavioural abnormalities and a de novo deletion of NRXN1alpha. JMedGenet 2008, 45(4):239-243.

17. Awadalla P, Gauthier J, Myers RA, Casals F, Hamdan FF, Griffing AR, Cote M, Henrion E, Spiegelman D, Tarabeux J, Piton A, Yang Y, Boyko A, Bustamante C, Xiong L, Rapoport JL, Addington AM, DeLisi JL, Krebs MO, Joober R, Millet B, Fombonne E, Mottron L, Zilversmit M, Keebler J, Daoud H, Marineau C, Roy-Gagnon MH, Dube MP, Eyre-Walker A, et al: Direct measure of the de novo mutation rate in autism and schizophrenia cohorts. Am J Hum Genet 2010, 87(3):316-324.

18. Bradley WE, Raelson JV, Dubois DY, Godin E, Fournier H, Prive C, Allard R, Pinchuk V, Lapalme M, Paulussen RJ, Belouchi A: Hotspots of large rare deletions in the human genome. PLoS One 2010, 5:(2):e9401.

19. Kirov G, Gumus D, Chen W, Norton N, Georgieva L, Sari M, O'Donovan MC, Erdogan F, Owen MJ, Ropers HH, Ullmann R: Comparative genome hybridization suggests a role for NRXN1 and APBA2 in schizophrenia. Hum Mol Genet 2008, 17(3):458-465.

20. Magri C, Sacchetti E, Traversa M, Valsecchi P, Gardella R, Bonvicini C, Minelli A, Gennarelli M, Barlati S: New copy number variations in schizophrenia. PLoS One 2010, 5:(10):e13422.

21. Mefford HC, Muhle H, Ostertag P, von Spiczak S, Buysse K, Baker C, Franke A, Malafosse A, Genton P, Thomas P, Gurnett CA, Schreiber S, Bassuk AG, Guipponi M, Stephani U, Helbig I, Eichler EE: Genome-wide copy number variation in epilepsy: novel susceptibility loci in idiopathic generalized and focal epilepsies. PLoS Genet 2010, 6(5):e1000962.

22. Szatmari P, Paterson AD, Zwaigenbaum L, Roberts W, Brian J, Liu XQ, Vincent JB, Skaug JL, Thompson AP, Senman L, Feuk L, Qian C, Bryson SE, Jones MB, Marshall CR, Scherer SW, Vieland VJ, Bartlett C, Mangin LV, Goedken R, Segre A, Pericak-Vance MA, Cuccaro ML, Gilbert JR, Wright HH, Abramson RK, Betancur C, Bourgeron T, Gillberg C, Leboyer M, et al: Mapping autism risk loci using genetic linkage and chromosomal rearrangements. Nat Genet 2007, 39(3):319-328.

23. Vrijenhoek T, Buizer-Voskamp JE, van dSI, Strengman E, Sabatti C, Geurts van KA, Brunner HG, Ophoff RA, Veltman JA: Recurrent CNVs disrupt three candidate genes in schizophrenia patients. AmJHumGenet 2008, 83(4):504-510.

24. Strauss KA, Puffenberger EG, Huentelman MJ, Gottlieb S, Dobrin SE, Parod JM, Stephan DA, Morton DH: Recessive symptomatic focal epilepsy and mutant contactin-associated protein-like 2. NEnglJMed 2006, 354(13):1370-1377.

25. Jackman C, Horn ND, Molleston JP, Sokol DK: Gene associated with seizures, autism, and hepatomegaly in an Amish girl. Pediatr Neurol 2009, 40(4):310-313.

26. Zweier $C$, de Jong EK, Zweier M, Orrico A, Ousager LB, Collins AL, Bijlsma EK, Oortveld MA, Ekici AB, Reis A, Schenck A, Rauch A: CNTNAP2 and NRXN1 are mutated in autosomal-recessive Pitt-Hopkins-like mental retardation and determine the level of a common synaptic protein in Drosophila. Am J Hum Genet 2009, 85(5):655-666.

27. Poliak S, Gollan L, Martinez R, Custer A, Einheber S, Salzer JL, Trimmer JS, Shrager P, Peles E: Caspr2, a new member of the neurexin superfamily, is localized at the juxtaparanodes of myelinated axons and associates with K+ channels. Neuron 1999, 24(4):1037-1047.

28. Zweier M, Gregor A, Zweier C, Engels $H$, Sticht $H$, Wohlleber E, Bijlsma EK, Holder SE, Zenker M, Rossier E, Grasshoff U, Johnson DS, Robertson L, Firth HV, Ekici AB, Reis A, Rauch A: Mutations in MEF2C from the $5 q 14.3 q 15$ microdeletion syndrome region are a frequent cause of severe mental retardation and diminish MECP2 and CDKL5 expression. Hum Mutat 2010, 31(6):722-733.

29. Girirajan S, Rosenfeld JA, Cooper GM, Antonacci F, Siswara P, Itsara A, Vives L, Walsh T, McCarthy SE, Baker C, Mefford HC, Kidd JM, Browning SR, Browning BL, Dickel DE, Levy DL, Ballif BC, Platky K, Farber DM, Gowans GC, Wetherbee JJ, Asamoah A, Weaver DD, Mark PR, Dickerson J, Garg BP, Ellingwood SA, Smith R, Banks VC, Smith W, et al: A recurrent 16p12.1 microdeletion supports a two-hit model for severe developmental delay. Nat Genet 2010, 42(3):203-209.

30. Katsanis $\mathrm{N}$ : The oligogenic properties of Bardet-Biedl syndrome. Hum Mol Genet 2004, 13(Spec No 1):R65-71.

31. Borozdin W, Boehm D, Leipoldt M, Wilhelm C, Reardon W, Clayton-Smith J, Becker K, Muhlendyck H, Winter R, Giray O, Silan F, Kohlhase J: SALL4 deletions are a common cause of Okihiro and acro-renal-ocular 
syndromes and confirm haploinsufficiency as the pathogenic mechanism. J Med Genet 2004, 41:(9):e113.

32. Engels $H$, Wohlleber E, Zink A, Hoyer J, Ludwig KU, Brockschmidt FF Wieczorek D, Moog U, Hellmann-Mersch B, Weber RG, Willatt L, KreissNachtsheim M, Firth HV, Rauch A: A novel microdeletion syndrome involving 5q14.3-q15: clinical and molecular cytogenetic characterization of three patients. Eur J Hum Genet 2009, 17(12):1592-1599.

33. Belloso JM, Bache I, Guitart M, Caballin MR, Halgren C, Kirchhoff M, Ropers HH, Tommerup N, Tumer Z: Disruption of the CNTNAP2 gene in a $\mathrm{t}(7 ; 15)$ translocation family without symptoms of Gilles de la Tourette syndrome. EurJHumGenet 2007, 15(6):711-713.

34. NNSplice 0.9. [http://www.fruitfly.org/seq_tools/splice.html]

35. HSF V2.4. [http://www.umd.be/HSF/.

36. MaxEntScan. [http://genes.mit.edu/burgelab/maxent/ Xmaxentscan_scoreseq.html].

37. Splice Site Score Calculation. [http://rulai.cshl.edu/new_alt_exon_db2/ HTML/score.html].

38. Splice Site Analyzer-Tool. [http://ibis.tau.ac.il/ssat/SpliceSiteFrame.htm]

39. Splice Predictor. [http://deepc2.psi.lastate.edu/cgi-bin/sp.cgi].

40. NetGene2. [http://www.cbs.dtu.dk/services/NetGene2/].

41. SplicePort. [http://spliceport.cs.umd.edu/].

\section{Pre-publication history}

The pre-publication history for this paper can be accessed here: http://www.biomedcentral.com/1471-2350/12/106/prepub

doi:10.1186/1471-2350-12-106

Cite this article as: Gregor et al:: Expanding the clinical spectrum associated with defects in CNTNAP2 and NRXN1. BMC Medical Genetics 2011 12:106

\section{Submit your next manuscript to BioMed Central} and take full advantage of:

- Convenient online submission

- Thorough peer review

- No space constraints or color figure charges

- Immediate publication on acceptance

- Inclusion in PubMed, CAS, Scopus and Google Scholar

- Research which is freely available for redistribution

Submit your manuscript at www.biomedcentral.com/submit 